\title{
Pd-W and Pd-Mo Catalysts for NO Decomposition and NO/CO Reduction Reactions
}

\author{
Rogério M. Dallago ${ }^{a}$ and Ione M. Baibich*,b \\ ${ }^{a}$ Departamento de Química, Universidade Regional Integrada do Alto Uruguai e das Missões, \\ Campus Erechim, Av. Sete de Setembro, 1621, 99700-000 Erechim-RS, Brazil \\ ${ }^{b}$ Instituto de Química, Universidade Federal do Rio Grande do Sul, Av. Bento Gonçalves \\ 9500, 91540-970 Porto Alegre-RS, Brazil
}

\begin{abstract}
Catalisadores $\mathrm{Pd} / \gamma-\mathrm{Al}_{2} \mathrm{O}_{3}$ com dois tamanhos de partículas metálicas foram preparados a partir de $\left[\mathrm{Pd}(\mathrm{acac})_{2}\right]$. Subsequentemente, a reação fotoquímica de $\left[\mathrm{M}(\mathrm{CO})_{6}\right](\mathrm{M}=\mathrm{Mo}$ ou $\mathrm{W})$ na presença de $\mathrm{Pd} / \gamma-\mathrm{Al}_{2} \mathrm{O}_{3}$ foi usada para preparar catalisadores bimetálicos $\mathrm{Pd}-\mathrm{M} / \gamma-\mathrm{Al}_{2} \mathrm{O}_{3}$. Os espectros DRIFTS-IVTF das superfícies destes catalisadores antes da decomposição térmica mostraram espécies subcarbonilas $\left[\mathrm{M}(\mathrm{CO})_{\mathrm{n}}\right]$ instáveis. Resultados de quimissorção e adsorção de $\mathrm{CO} / \mathrm{NO}$ indicaram um bloqueio dos sítios ativos do paládio quando o segundo metal foi incorporado. A atividade catalítica e a seletividade para $\mathrm{N}_{2}$ e $\mathrm{O}_{2}$ na reação $\mathrm{NO} / \mathrm{CO}$ foram maiores para Pd com maior tamanho de partícula, mas foram inibidas quando Mo ou W foram incorporados. Por outro lado, quando esses catalisadores foram testados para a decomposição de NO, a presença de Mo ou W levou a um aumento da atividade catalítica e da seletividade, com os melhores resultados observados na presença de Mo.
\end{abstract}

$\mathrm{Pd} / \gamma-\mathrm{Al}_{2} \mathrm{O}_{3}$ catalysts with two different metal particle sizes were prepared from $\left[\mathrm{Pd}(\mathrm{acac})_{2}\right]$. Subsequently, the photochemical reaction of $\left[\mathrm{M}(\mathrm{CO})_{6}\right](\mathrm{M}=\mathrm{Mo}$ or $\mathrm{W})$ in the presence of $\mathrm{Pd} / \gamma-\mathrm{Al}_{2} \mathrm{O}_{3}$ was used to prepare bimetallic $\mathrm{Pd}-\mathrm{M} / \gamma-\mathrm{Al}_{2} \mathrm{O}_{3}$ catalysts. DRIFTS FTIR spectra of the catalyst surfaces prior to thermal decomposition showed unstable subcarbonyl $\left[\mathrm{M}(\mathrm{CO})_{n}\right]$ species. Chemisorption and $\mathrm{CO} / \mathrm{NO}$ adsorption results indicated a blockage of the Pd active sites when the second metal was incorporated. The catalytic activity and the selectivity for the $\mathrm{NO} / \mathrm{CO}$ reaction were higher for $\mathrm{Pd}$ with higher particle size, but they were both inhibited when Mo or $\mathrm{W}$ were incorporated. On the other hand, when the catalysts were tested for NO decomposition, the presence of Mo or W led to an increase in the catalytic activity, with optimal results observed in the presence of Mo.

Keywords: NO decomposition, NO/CO reduction, palladium/alumina catalyst, molybdenum, tungsten

\section{Introduction}

The removal of $\mathrm{NO}_{\mathrm{x}}$ species is among the most relevant issues in environmental chemistry. ${ }^{1,2}$ Since NO is thermodynamically unstable relative to $\mathrm{N}_{2}$ and $\mathrm{O}_{2}$ at low temperatures, the catalytic decomposition of $\mathrm{NO}$ to give these two elements presents a simple and attractive method for removal. ${ }^{2}$ To this end, a number of metals and inorganic supports have been developed. ${ }^{3,4}$

There has been a growing interest in the use of palladium as the active metal for exhaust catalysts. Studies have shown that $\mathrm{Pd}$ can catalyze the reduction of $\mathrm{NO}$ to $\mathrm{N}_{2}$, in addition to its activity for hydrocarbon and $\mathrm{CO}$ oxidation. ${ }^{5-11}$ However, in

*e-mail: ione@iq.ufrgs.br the presence of hydrocarbons, the NO reducing capacity of $\mathrm{Pd}$ is lower than that reported for Rh-based catalysts. ${ }^{8,12}$ In order to overcome this problem while employing relatively inexpensive metals, bimetallic Pd-Mo and Pd-W catalysts have been proposed. ${ }^{13-21}$ Using inorganic salt precursors, catalysts with adequate metal-metal contacts can be prepared and employed, but they require the use of high catalyst loadings, which might lead to tungsten or molybdenum oxide vapors. ${ }^{17}$

Previously, we have shown that $\mathrm{Pd}-\mathrm{M} / \gamma-\mathrm{Al}_{2} \mathrm{O}_{3}(\mathrm{M}=\mathrm{Mo}$ or $\mathrm{W}$ ) prepared from the photochemical activation of the organometallic precursor $\left[\mathrm{M}(\mathrm{CO})_{6}\right]$ displayed Pd-M interactions with low metal loadings and led to an enhanced activity for NO decomposition with $\mathrm{M}=\mathrm{W} \cdot{ }^{22-26}$ Furthermore, we have studied different solid supports, such as zeolites ${ }^{27,28}$ and mesoporous materials. ${ }^{29-31}$ 
Herein, we describe the preparation of the bimetallic catalysts $\mathrm{Pd}-\mathrm{Mo} / \gamma-\mathrm{Al}_{2} \mathrm{O}_{3}$ and $\mathrm{Pd}-\mathrm{W} / \gamma-\mathrm{Al}_{2} \mathrm{O}_{3}$ from the photochemical activation of $\left[\mathrm{M}(\mathrm{CO})_{6}\right](\mathrm{M}=\mathrm{Mo}$ and $\mathrm{W})$ on alumina, and we investigate the influence of the metal particle size and of the presence of a second metal on the catalysts performance. The catalysts obtained by this method were characterized by Fourier-transform infrared spectroscopy (FTIR) analysis of adsorbed CO and NO, $\mathrm{H}_{2}$ chemisorption, and metal content determination by atomic absorption spectroscopy (AAS). The activities of the catalysts were investigated for $\mathrm{NO}+\mathrm{CO}$ and $\mathrm{NO}$ decomposition reactions.

\section{Experimental}

\section{Catalyst synthesis}

Alumina $\left(\gamma-\mathrm{Al}_{2} \mathrm{O}_{3}, 96 \mathrm{~m}^{2} \mathrm{~g}^{-1}\right.$, Rhône-Poulenc) was activated at $973 \mathrm{~K}$ for three hours in synthetic air, followed by $1 \mathrm{~h}$ in vacuum at the same temperature.

The palladium on alumina catalyst $\left(\mathrm{Pd} / \gamma-\mathrm{Al}_{2} \mathrm{O}_{3}\right)$ was prepared by the wet impregnation technique using a toluene solution of palladium acetylacetonate ([Pd(acac) ${ }_{2}$, Aldrich, $2.2 \mathrm{mg} \mathrm{mL}^{-1}$ ) and activated alumina, left in contact for $24 \mathrm{~h}$ at room temperature. After impregnation, the liquid was removed, and the solid was activated in air at $573 \mathrm{~K}$ for $2 \mathrm{~h}$ and then reduced in flowing hydrogen at the same temperature for $2 \mathrm{~h}$, as previously detailed. ${ }^{22,23}$ This catalyst was named $\mathrm{Pd} / \gamma-\mathrm{Al}_{2} \mathrm{O}_{3}$. A certain amount of this catalyst was subjected to a sintering process by further reduction with $\mathrm{H}_{2}$ for $10 \mathrm{~h}$ at $773 \mathrm{~K}$, producing the desired $\mathrm{Pd}_{\text {sint }} / \gamma-\mathrm{Al}_{2} \mathrm{O}_{3}$ catalyst.

The bimetallic Pd-Mo and Pd-W catalysts were prepared using palladium-alumina as support and performing a photochemical activation of $\left[\mathrm{M}(\mathrm{CO})_{6}\right]$, where $\mathrm{M}=\mathrm{Mo}$ or $\mathrm{W}$. This was accomplished by adding $2 \mathrm{~g}$ of $\mathrm{Pd} / \gamma-\mathrm{Al}_{2} \mathrm{O}_{3}$ to a degassed and dried hexane solution of the metal carbonyl compound $\left(77 \mathrm{mg}\left[\mathrm{W}(\mathrm{CO})_{6}\right]\right.$ and $\left.83 \mathrm{mg}\left[\mathrm{Mo}(\mathrm{CO})_{6}\right]\right)$ aiming to achieve $2 \mathrm{wt} \%$ metal, under $\mathrm{N}_{2}$, using Schlenk techniques. The closed reaction vessel was irradiated for $6 \mathrm{~h}$ with a UV Hg lamp fitted into a cold finger. FTIR analysis of the solution and DRIFTS (Diffuse Reflectance Infrared Fourier Transform Spectroscopy) analysis of the support were subsequently carried out. The solid was then separated by filtration, dried under vacuum at $723 \mathrm{~K}$ and stored under argon. The percent content of Pd, W and Mo was determined by AAS.

\section{DRIFTS FTIR spectra}

Diffuse Reflectance (DRIFTS) spectra were recorded at 293 K on a Bomem MB-102 spectrometer, with 32 scans and a resolution of $4 \mathrm{~cm}^{-1}$. The study was restricted to the $v(\mathrm{CO})$ region $\left(2200-1700 \mathrm{~cm}^{-1}\right)$. The solid phases were analyzed as powders in a DRIFTS accessory equipped with sampling cups. These were filled with the support powder and transferred immediately to the equipment to prevent decomposition. The spectra were collected in reflectance units and transformed to Kubelka-Munk (KM) units.

\section{Hydrogen chemisorption}

Hydrogen chemisorption measurements were made in conventional volumetric equipment at $298 \mathrm{~K}$, employing pulses with varying $\mathrm{H}_{2}$ pressures (between 60 and 270 torr). The samples were initially treated with $\mathrm{H}_{2}$ at $573 \mathrm{~K}$ for $1 \mathrm{~h}$, followed by vacuum for 18 to $20 \mathrm{~h}$, and by cooling under vacuum to $298 \mathrm{~K}$. The amount of absorbed hydrogen forming $\alpha$ and $\beta$ palladium hydrides was measured after vacuum at room temperature and subtracted. The dispersion values or the exposed palladium ratio (Pds/Pd) were determined from the difference between the two relevant isotherms (the first one gives the total adsorbed and absorbed amount of hydrogen, while the second measures only the absorbed $\mathrm{H}_{2}$ ) that corresponds only to strongly chemisorbed hydrogen $\left(\mathrm{H}_{\text {irrev }}\right)$ and extrapolated to zero pressure, assuming $\mathrm{H}_{\text {irrev }}$ :metal proportion of 1:1. The crystallite size based on chemisorption measurements was estimated from the equation: ${ }^{32} \mathrm{~d}(\mathrm{~nm})=1.12$ (percentage of exposed metal) ${ }^{-1}$. This expression assumes hemispherical particles and a surface atom density of $1.27 \times 10^{19}$ atom $\mathrm{m}^{-2}$.

\section{$\mathrm{CO}$ and NO adsorption measurements}

A Nicolet 20 DXB FTIR instrument at $4 \mathrm{~cm}^{-1}$ resolution was used to identify the $\mathrm{CO}$ species adsorbed on the catalysts surfaces. Catalyst samples of approximately $30 \mathrm{mg}$ were pressed to form transparent $10 \mathrm{~mm}$ diameter disks, which were placed in a heated metal holder. The holder was placed in the beam path of a stainless steel cell sealed with $\mathrm{CaF}_{2}$ windows, and coupled to a vacuum system for evacuation to $10^{-6}$ torr. It was possible to perform heat treatments up to $573 \mathrm{~K}$, to dose $\mathrm{CO}$ or NO through a leak valve, or to maintain a steady flow of $\mathrm{H}_{2}$ or $\mathrm{He}$. An MKS Baratron Type $170 \mathrm{M}$ allowed pressure measurements to be made in the 0.1-10 torr range.

After reduction in flowing $\mathrm{H}_{2}$ at $573 \mathrm{~K}$, the samples were cooled to room temperature under a steady stream of $\mathrm{He}$. The adsorbate was dosed at pressures of 1 to 5 torr, and the samples were exposed to $\mathrm{CO}$ or NO prior to spectra measurement. Scanning times were approximately $1 \mathrm{~min}$. Finally, the cell was evacuated to $10^{-5}$ torr for $2 \mathrm{~min}$, and a new spectrum was accumulated. 


\section{Catalytic activity measurements}

Catalytic experiments were carried out in a flow reactor mounted in an electric furnace. Catalysts samples $(0.3 \mathrm{~g}$ for the $\mathrm{NO}$ reaction and $0.022 \mathrm{~g}$ for the $\mathrm{NO}+\mathrm{CO}$ reaction) were packed in a $0.6 \mathrm{~mm}$ internal diameter stainless steel (SS) tube with a thermocouple placed at the reactor entrance. The NO decomposition reactions were studied as a function of time at $723 \mathrm{~K}, 753 \mathrm{~K}$ and $773 \mathrm{~K}$ using a mixture containing $370 \mathrm{ppm}$ of NO in a He background (Matheson, certified), and the flow rate was adjusted to $75 \mathrm{~mL} \mathrm{~min}^{-1}$. Prior to reaction, the catalysts were reduced in situ with $\mathrm{H}_{2}$ for $45 \mathrm{~min}$ at the reaction temperature.

The $\mathrm{NO}+\mathrm{CO}$ reactions were studied as a function of temperature. The catalyst was treated with the reaction mixture (550 ppm of $\mathrm{NO}$ and $550 \mathrm{ppm}$ of $\mathrm{CO}$ in $\mathrm{He}$ ) for $35 \mathrm{~min}$ at $673 \mathrm{~K}$ prior to all measurements. The flow

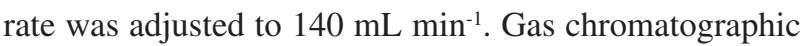
separation of reactants and products was achieved by two Porapak Q columns: the first (1/8 in. x $6 \mathrm{~m}$ ) was employed for the separation of $\mathrm{NO}, \mathrm{O}_{2}$ and $\mathrm{N}_{2}$ at $263 \mathrm{~K}$, and the second $(1 / 8$ in. $x 2.4 \mathrm{~m})$ was employed for the separation of $\mathrm{N}_{2} \mathrm{O}$ and $\mathrm{CO}_{2}$ at $313 \mathrm{~K}$.

\section{Results and Discussion}

\section{Adsorbed metal carbonyl FTIR spectra}

DRIFTS spectral analysis of solid samples immediately after the photochemical reaction and prior to thermal decomposition indicated the $\left[\mathrm{M}(\mathrm{CO})_{6-\mathrm{n}}\right](\mathrm{n}=1-6)$ uptake on the support, as shown in Figure 1. The spectrum was recorded in inert atmosphere to allow the detection of the bands, since these species decompose rapidly in the absence of a stabilizing ligand such as $\mathrm{PPh}_{3}{ }^{25,26}$

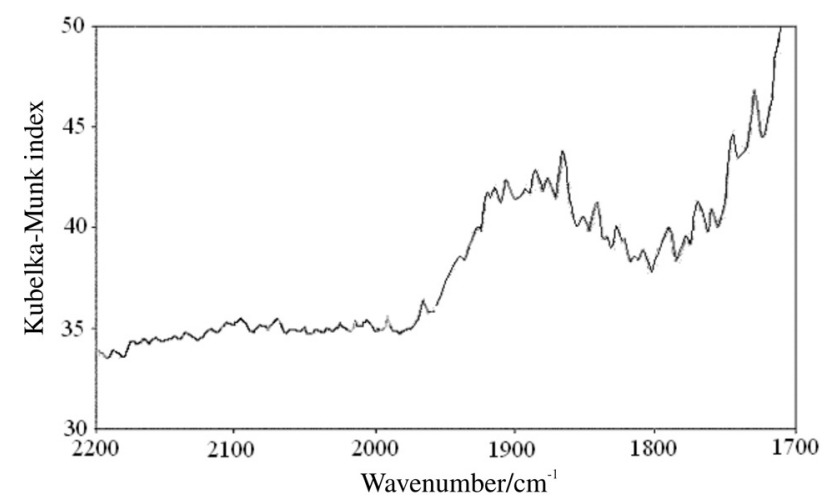

Figure 1. DRIFTS IR spectrum in the $v(\mathrm{CO})$ region of $\mathrm{Pd}_{\text {sint }} / \gamma-\mathrm{Al}_{2} \mathrm{O}_{3}$ after $6 \mathrm{~h}$ reaction.

The photochemical activation was monitored by measurement of the decrease in the $\left[\mathrm{M}(\mathrm{CO})_{6}\right] \mathrm{t}_{1 \mathrm{u}}$ mode of the $v(\mathrm{CO})$ stretching band in the hexane solution spectrum. When the support was $\mathrm{Pd}_{\text {sint }} / \gamma-\mathrm{Al}_{2} \mathrm{O}_{3}$, the solution displayed bands at 2078 and $1948 \mathrm{~cm}^{-1}$ at the zero time point (Figure 2a). This was in direct contrast to the $\mathrm{Pd} / \gamma-\mathrm{Al}_{2} \mathrm{O}_{3}$ support spectrum, in which the Pd was not submitted to high temperature reduction, even after $6 \mathrm{~h}$. In this case, the metal hexacarbonyl band remained unchanged (Figure 2b). The bands shown in Figure $2 \mathrm{a}$ are indicative of an $\left[\mathrm{M}(\mathrm{CO})_{5}\right]$ species shifted to higher wavenumbers relative to $\left[\mathrm{M}(\mathrm{CO})_{5} \mathrm{PPh}_{3}\right]$, where the phosphine ligand acts as a Lewis base. The larger Pd particles were determined to be reactive toward $\mathrm{CO}$, and even prior to photochemical activation, the tungsten hexacarbonyl loses one $\mathrm{CO}$ that likely coordinates to $\mathrm{Pd}$.
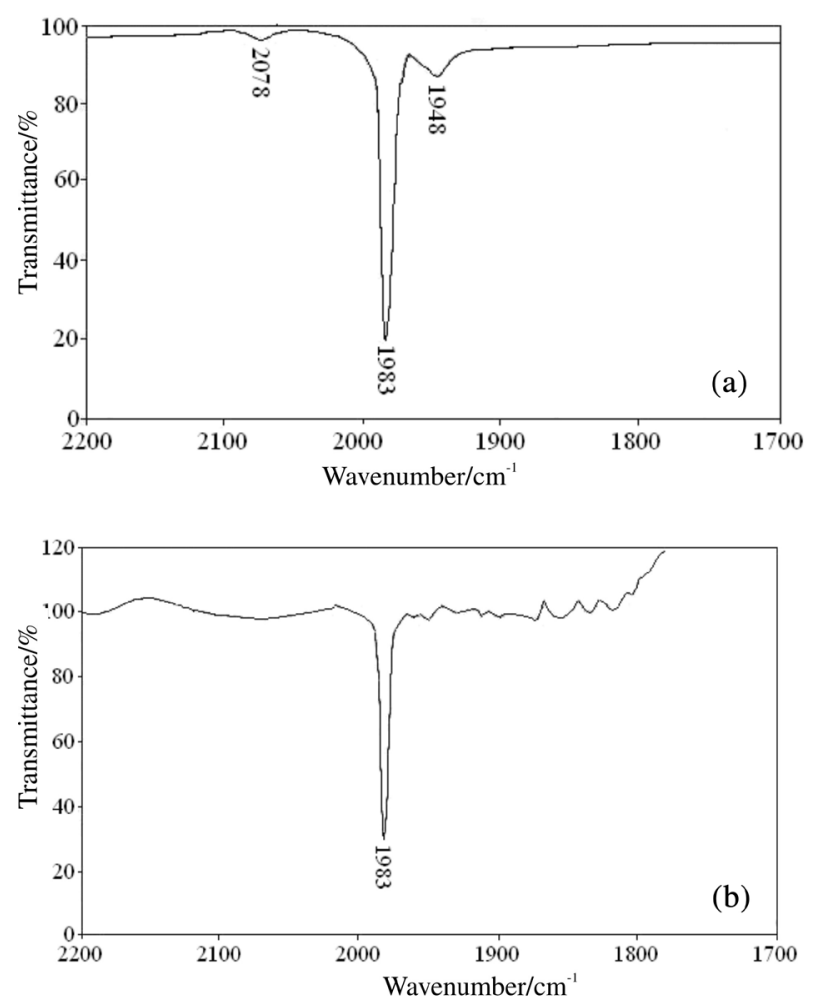

Figure 2. Spectra of $\left[\mathrm{W}(\mathrm{CO})_{6}\right]$ in hexane solution (a) after immediate contact with $\mathrm{Pd}_{\text {sint }} / \gamma-\mathrm{Al}_{2} \mathrm{O}_{3}$; (b) after $6 \mathrm{~h}$ contact with $\mathrm{Pd} / \gamma-\mathrm{Al}_{2} \mathrm{O}_{3}$.

\section{Catalysts characterization}

Table 1 presents catalyst loadings, dispersions, and particle sizes determined for the present study. It is evident that the $\mathrm{Pd}_{\text {sint }} / \gamma-\mathrm{Al}_{2} \mathrm{O}_{3}$ catalyst presents a reduction in the dispersion and a subsequent increase in particle size relative to $\mathrm{Pd} / \gamma-\mathrm{Al}_{2} \mathrm{O}_{3}$. The high-temperature reduction led to a pronounced particle agglomeration. There is also a decrease in $\mathrm{Pd} \mathrm{H}_{2}$ adsorption caused by $\mathrm{Mo}$ or $\mathrm{W}$ in the bimetallic catalysts. This effect can be attributed to a blockage of the palladium-exposed surface by the second metal, preventing 
two adjacent $\mathrm{Pd}$ atoms to adsorb $\mathrm{H}_{2}$. Similar results were reported by Schmal et al. ${ }^{16}$ for $\mathrm{Pd}-\mathrm{MoO}_{3} /$ alumina catalysts prepared from inorganic salts.

Table 1. Catalysts loadings and hydrogen chemisorption

\begin{tabular}{lccccc}
\hline Catalysts & $\mathrm{Pd}$ & $\mathrm{W}$ & $\mathrm{Mo}$ & $\begin{array}{c}\text { Dispersion } \\
\mathrm{Pd}_{\mathrm{S}} / \mathrm{Pd}_{\mathrm{T}}\end{array}$ & $\begin{array}{c}\mathrm{dp} / \mathrm{nm} \\
\mathrm{Chem} \cdot \mathrm{H}_{2}{ }^{\mathrm{a}}\end{array}$ \\
\hline $\mathrm{Pd}$ & 0.87 & - & - & 0.66 & 1.7 \\
$\mathrm{Pd}_{\text {sint }}$ & 0.87 & - & - & 0.40 & 2.8 \\
$\mathrm{Pd}_{\text {sint }} \mathrm{Mo}$ & 0.87 & - & 1.0 & 0.28 & - \\
$\mathrm{Pd}_{\text {sint }} \mathrm{W}$ & 0.87 & 0.66 & - & 0.24 & - \\
\hline
\end{tabular}

${ }^{\mathrm{a} A s s u m i n g ~ s e m i s p h e r i c a l ~ p a r t i c l e s: ~} \mathrm{dp}=1.12\left(\mathrm{Pd}_{\mathrm{S}} / \mathrm{Pd}_{\mathrm{T}}\right)^{-1}$.

\section{$\mathrm{CO}$ and $\mathrm{NO}$ adsorption measurements}

Figure 3 shows the FTIR spectra of the $v(\mathrm{CO})$ region for the two catalysts after 5 min $\mathrm{CO}$ exposure and subsequent 2 min under vacuum. The bands are typical for $\mathrm{CO}$ adsorbed on Pd. The band at higher wavenumber (ca. $2075 \mathrm{~cm}^{-1}$ ) is attributed to linear $\mathrm{CO}$, and the bands at 1958 and $1908 \mathrm{~cm}^{-1}$ are attributed to bridging CO. There is a clear lowering of the linear $\mathrm{CO}$ band intensity and a concomitant increase in the bridging $\mathrm{CO}$ band with the sintering process. This is in accordance with the results shown in Table 1, which suggest that the larger Pd particles present shorter Pd atom distances and a higher probability for $\mathrm{CO}$ to bind in a bridging manner. Additionally, the weak band at $2110 \mathrm{~cm}^{-1}$, which disappears in $\mathrm{Pd}_{\text {sint }}$ I $\gamma-\mathrm{Al}_{2} \mathrm{O}_{3}$, is attributed to $\mathrm{Pd}^{+}$species.

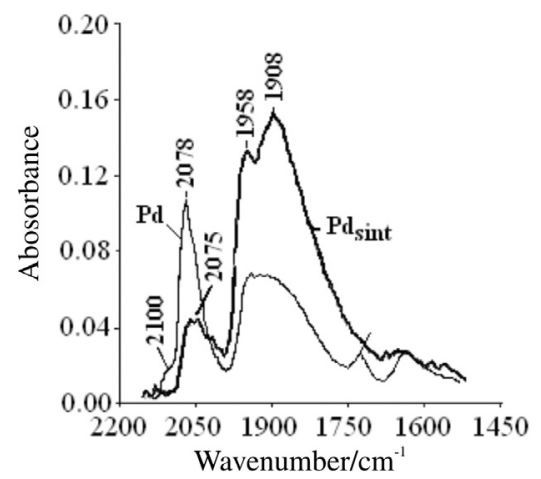

Figure 3. FTIR spectra of the $v(\mathrm{CO})$ region of $\mathrm{Pd} / \gamma-\mathrm{Al}_{2} \mathrm{O}_{3}$ and $\mathrm{Pd}_{\text {sim }} / \gamma-\mathrm{Al}_{2} \mathrm{O}_{3}$ catalysts after $5 \mathrm{~min} \mathrm{CO}$ exposure followed by $2 \mathrm{~min}$ under vacuum.

The effect of the second metal atom in the sintered bimetallic catalysts was to lower both the bridging and the linear CO band intensities (Figure 4). It is well known that Mo and $\mathrm{W}$ adsorb $\mathrm{CO}$ only under extremely harsh conditions $(>873 \mathrm{~K})$, and in the present case the band shapes are similar to those in Figure 3. As such, it can be assumed that they are due to $\mathrm{CO}$ adsorbed on $\mathrm{Pd}^{32-36}$ The same behavior was previously observed with the Pd-W/ $\mathrm{Al}_{2} \mathrm{O}_{3}$ catalyst. ${ }^{25}$ Additionally, there is a decrease in the probability of having two adjacent $\mathrm{Pd}$ atoms binding $\mathrm{CO}$ in a bridging manner. An electronic effect caused by the presence of Mo or W was not detected, since there is not a significant shift in the $v(\mathrm{CO})$ bands.

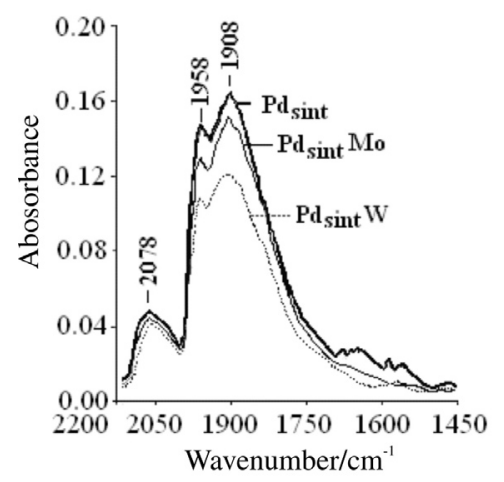

Figure 4. FTIR spectra of the $\mathrm{v}(\mathrm{CO})$ region of $\mathrm{Pd}_{\text {sin }} / \gamma-\mathrm{Al}_{2} \mathrm{O}_{3}, \mathrm{Pd}_{\text {sint }}-\mathrm{Mo} / \gamma$ $\mathrm{Al}_{2} \mathrm{O}_{3}, \mathrm{Pd}_{\text {sint }}-\mathrm{W} / \gamma-\mathrm{Al}_{2} \mathrm{O}_{3}$ catalysts after $5 \mathrm{~min} \mathrm{CO}$ exposure followed by 2 min under vacuum.

The spectra of the $v(\mathrm{NO})$ region for the $\mathrm{Pd}_{\text {sint }}$ catalysts after NO exposure are shown in Figure 5. The band near $1730 \mathrm{~cm}^{-1}$ is attributed to $\mathrm{v}(\mathrm{NO})$ terminal stretching band, and the band at $1626 \mathrm{~cm}^{-1}$ is assigned to bridging NO. The bands that appear at lower wavenumbers might be attributed to multi-coordinated $\mathrm{NO}$ or, as reported before, ${ }^{25}$ to carbonates from a possibly contaminated surface, as $\mathrm{CO}$ adsorption was measured before the measurements with NO. There is a decrease in band intensity in the presence of the second metal (Mo or W), with this effect being higher for $\mathrm{W}$. This is in accordance with the results found for $\mathrm{CO}$ adsorption described above.

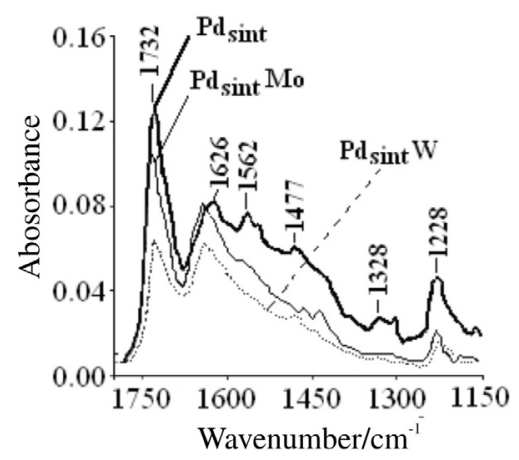

Figure 5. FTIR spectra of the $v(\mathrm{NO})$ region of $\mathrm{Pd}_{\text {sint }} / \gamma-\mathrm{Al}_{2} \mathrm{O}_{3}, \mathrm{Pd}_{\text {sint }}-\mathrm{Mo} / \gamma$ $\mathrm{Al}_{2} \mathrm{O}_{3}, \mathrm{Pd}_{\text {sint }}-\mathrm{W} / \gamma-\mathrm{Al}_{2} \mathrm{O}_{3}$ catalysts after $5 \mathrm{~min} \mathrm{NO}$ exposure followed by 2 min under vacuum.

\section{Catalytic activities results}

The prepared catalysts were tested for the $\mathrm{NO}+\mathrm{CO}$ reduction reaction as a function of temperature. Figure 6 shows the monometallic Pd catalyst behavior. The results 
indicate that the larger particle size catalyst presented slightly higher activities to both $\mathrm{CO}$ oxidation and NO reduction. Furthermore, higher selectivities toward $\mathrm{N}_{2}$ and lower selectivities toward $\mathrm{N}_{2} \mathrm{O}$ were observed in temperatures above $573 \mathrm{~K}$. The proximity of the Pd active site appears to explain this higher activity. Using the NO conversion values at $523 \mathrm{~K}$ (Figure 6), the number of molecules that were converted per second calculated from the reaction conditions (experimental part) and the hydrogen chemisorption values reported in Table 1 , which allow the estimation of the number of Pd atoms, the turnover frequency $\left(\mathrm{TOF}_{\mathrm{NO}}\right.$ ) was estimated to be $14.48 \times 10^{-3}$ for $\mathrm{Pd} / \gamma-\mathrm{Al}_{2} \mathrm{O}_{3}$ and $35.84 \times 10^{-3}$ for $\mathrm{Pd}_{\text {sint }} / \gamma-\mathrm{Al}_{2} \mathrm{O}_{3}$. On the other hand, the presence of Mo or $\mathrm{W}$ on the $\mathrm{Pd}_{\text {sint }}$ catalyst (Figure 7) did not significantly decrease the activity for NO reduction; rather, it inhibited $\mathrm{CO}$ oxidation and $\mathrm{N}_{2}$ production and increased the overall $\mathrm{N}_{2} \mathrm{O}$ concentration.
These results suggest that the presence of $\mathrm{W}$ or Mo did not improve the reaction performance in the presence of $\mathrm{CO}$.

Figure 8 illustrates the NO conversion values versus time at $773 \mathrm{~K}$ for the $\mathrm{NO}$ decomposition reaction using $\mathrm{Pd}_{\text {sint }} / \gamma-\mathrm{Al}_{2} \mathrm{O}_{3}$ catalysts. After $10 \mathrm{~min}$, the catalysts were nearly completely deactivated. Production of $\mathrm{N}_{2} \mathrm{O}$ was not detected using the monometallic Pd catalyst, which indicates complete $\mathrm{NO}$ reduction. When the second metal was $\mathrm{W}$, only traces of $\mathrm{N}_{2} \mathrm{O}$ were observed $(<1 \mathrm{ppm})$, and the $\mathrm{O}_{2}$ production was high (10 to $15 \mathrm{ppm}$ ), indicating nearly complete NO reduction. The $\mathrm{Pd}_{\text {sint }}-$ Mo catalyst presented a different behavior, in which high conversion and residual activities higher than for $\mathrm{Pd}_{\text {sint }}$ and $\mathrm{Pd}_{\text {sint }}-\mathrm{W}$ catalysts were observed for extended periods of time. Furthermore, the starting point of $\mathrm{N}_{2} \mathrm{O}$ production coincides with a decrease in total $\mathrm{NO}$ conversion after $10 \mathrm{~min}$. Analogous behavior was also observed in the $\mathrm{Pd} / \gamma-\mathrm{Al}_{2} \mathrm{O}_{3}$ based catalysts with

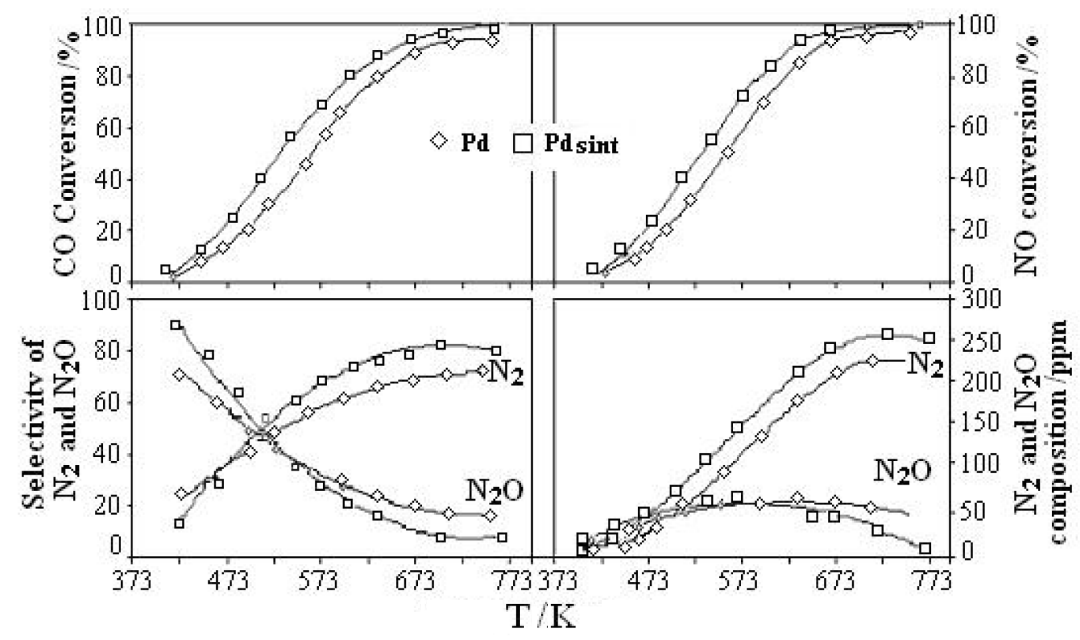

$\mathrm{Pd}[\diamond] \quad \mathrm{Pd}_{\sin }[\square]$

Figure 6. Conversion versus temperature and selectivity in the $\mathrm{NO}+\mathrm{CO}$ reactions. Catalysts are $\mathrm{Pd} / \gamma-\mathrm{Al}_{2} \mathrm{O}_{3}$ and $\mathrm{Pd}_{\sin } / \gamma-\mathrm{Al}_{2} \mathrm{O}_{3}$.

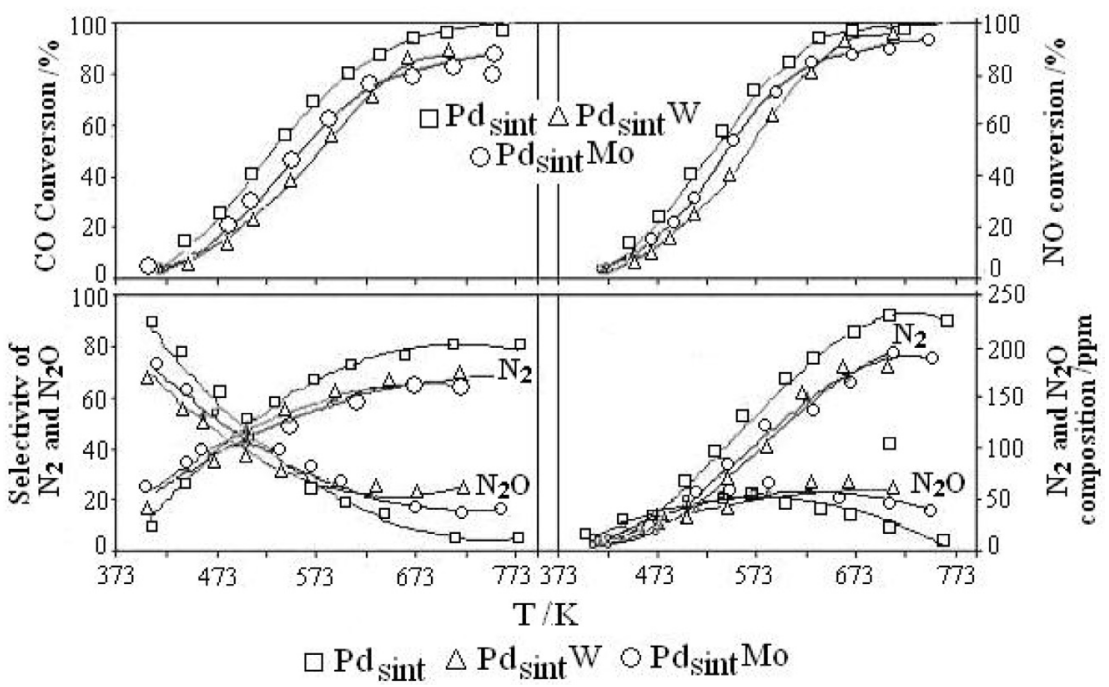

Figure 7. Conversion versus temperature and selectivity in the $\mathrm{NO}+\mathrm{CO}$ reaction. Catalysts are $\mathrm{Pd}_{\text {sint }} \mathrm{Pd}_{\text {sint }} \mathrm{W}$ and $\mathrm{Pd}_{\text {sint }} \mathrm{Mo}$. 


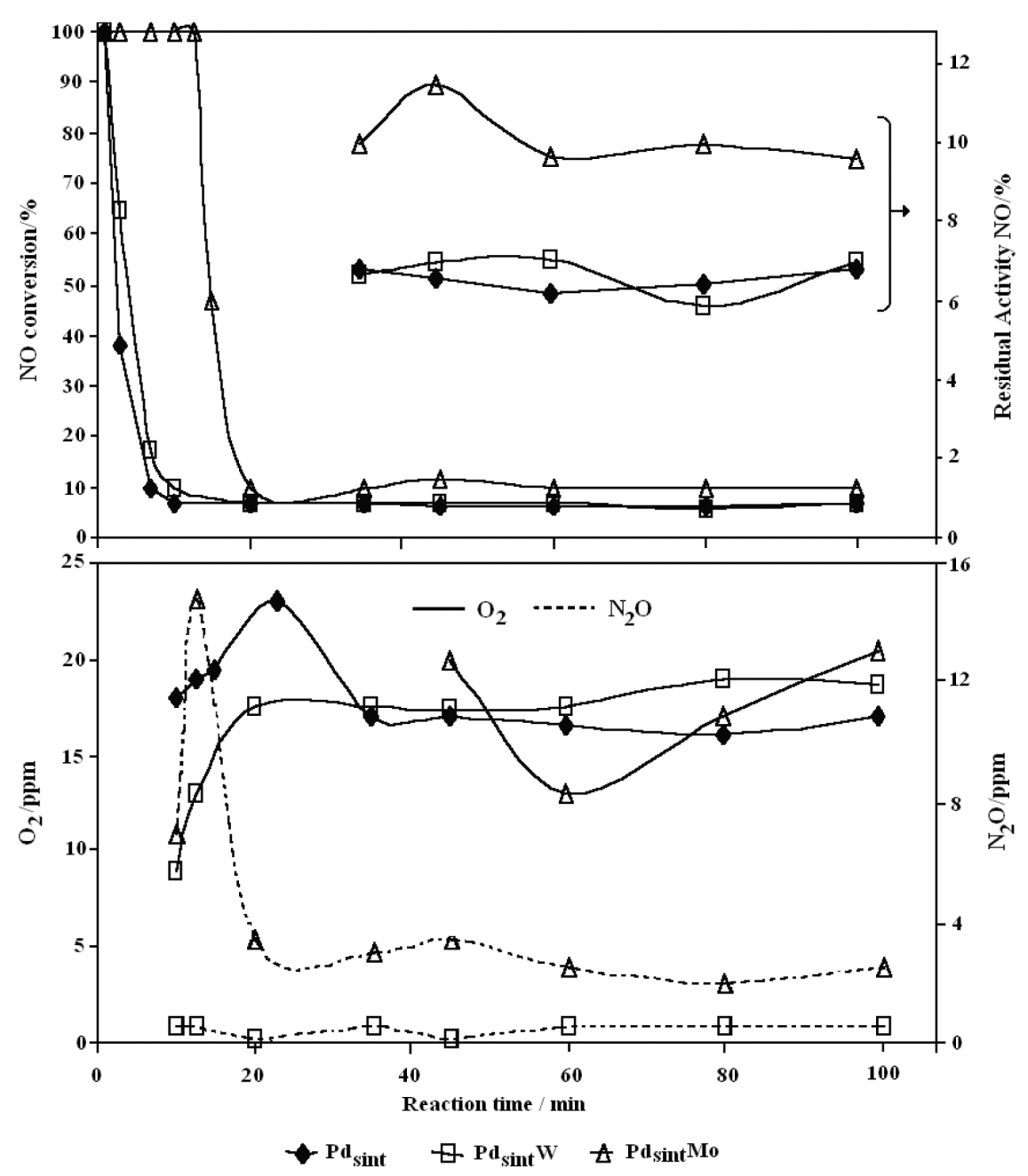

Figure 8. Activity evolution (a) and $\mathrm{O}_{2}$ and $\mathrm{N}_{2} \mathrm{O}$ formation (b) for $\mathrm{Pd}_{\text {sint }}$ catalysts at $773 \mathrm{~K}$ in the NO decomposition reaction.

smaller size particles (data not shown). Table 2 shows the activation energies found for these catalysts in the temperature range between 723 and $773 \mathrm{~K}$. It is evident that the presence of Mo results in a significant decrease in the activation energy for the NO reduction reaction.

Table 2. Activation energy values for NO reduction

\begin{tabular}{lcccc}
\hline Catalyst & $\mathrm{Pd}$ & $\begin{array}{c}\text { \%metal } \\
\mathrm{W}\end{array}$ & $\mathrm{Mo}$ & $\begin{array}{c}\mathrm{E}_{\mathrm{a}} / \\
\left(\mathrm{kcal} \mathrm{mol}^{-1}\right)\end{array}$ \\
\hline $\mathrm{Pd}_{\text {sint }}$ & 0.87 & - & - & 22.31 \\
$\mathrm{Pd}_{\text {sint }} \mathrm{W}$ & 0.87 & 0.66 & - & 19.63 \\
$\mathrm{Pd}_{\text {sint }} \mathrm{Mo}$ & 0.87 & & 1.0 & 8.35 \\
\hline
\end{tabular}

The IR CO and NO bands (Figures 4 and 5) were not shifted when $\mathrm{W}$ or Mo were present, and therefore changes in the surface electronic properties of Pd were not detected. As Mo does not block the Pd active sites, differently from $\mathrm{W}$, even being in higher loadings, the promotional effect of Mo can be attributed to adsorption and dissociation of NO on partially reduced Mo atoms. This effect is in accordance with the results reported by Schmal et al. ${ }^{34}$ comparing activities and selectivities of Pd and $\mathrm{Pd}-\mathrm{MoO}_{3}$ catalysts. The authors found that both catalysts gave the same conversion, although the fraction of exposed metal atoms decreased substantially in the presence of $7.5 \% \mathrm{Mo}$. In our case, where Mo is in a low oxidation state (as the catalyst precursor contained $\mathrm{Mo}^{0}$ ), the effect is accentuated in accordance with the results found. Finally, in comparison with $\mathrm{W}$, the better result for Mo may be related to the lower reduction temperature of Mo.

\section{Conclusions}

It has been demonstrated that Pd particles with larger sizes are more active and selective towards the $\mathrm{NO}+\mathrm{CO}$ reduction reaction. The photochemical activation of metal carbonyls provided synthetic access to bimetallic Pd-Mo and Pd-W catalysts. The activities and selectivities of these bimetallic catalysts were lowered by the presence of $\mathrm{W}$ or 
Mo in the NO reduction by CO. However, these bimetallic catalysts were more active and selective in the direct NO decomposition reaction, with optimal results observed for the Mo-containing catalyst.

\section{Acknowledgments}

This work was supported by CNPq, FAPERGS and CAPES (Brazil). We are grateful to Carlos Gigola, PLAPIQUI, Bahia Blanca, Argentina, for the use of his laboratory facilities.

\section{References}

1. Liu, Z.; Woo, S. I.; Catal. Rev. 2006, 48, 43.

2. Fritz, A.; Pitchon, V.; Appl. Catal., B 1997, 13, 1.

3. Taylor, K. C.; Appl. Catal., B 1993, 35, 457.

4. Summers, J. C.; Monroe, D. R.; Ind. Eng. Chem. Prod. Res. Dev. 1981, 20, 23.

5. Burch, R.; Ramli, A.; Appl. Catal., B 1998, 15, 49.

6. Obuchi, A.; Ohi, A.; Nakamura, M.; Ogata, A.; Mizuno, K.; Ohuchi, H.; Appl. Catal., B 1993, 2, 71.

7. Hecker, W. C.; Bell, A. T.; J. Catal. 1983, 84, 200.

8. Muraki, H.; Shinjoh, H.; Fujitani, Y.; Ind. Eng. Chem. Prod. Res. Dev. 1986, 25, 419 .

9. Pieterse, J. A. Z.; Booneveld, S.; Appl. Catal., B 2007, 73, 327.

10. Granger, P.; Dujardin, C.; Paul, J. F.; Leclerq, G.; J. Mol. Catal. A: Chem. 2005, 228, 241.

11. Granger, P.; Dhainaut, F.; Pietrzik, S.; Malfoy, P.; Mamede, A.S.; Leclerq, L.; Leclerq, G.; Top. Catal. 2006, 39, 65.

12. Shelef, M.; Graham, G. W.; Catal. Rev. - Sci. Eng. 1994, 36, 433.

13. Halasz, I.; Brenner, A.; Shelef, M.; Catal. Lett. 1992, 16, 311.

14. Halasz, I.; Brenner, A.; Shelef, M.; Catal. Lett. 1993, 18, 289.

15. Halasz, I.; Brenner, A.; Shelef, M.; Appl. Catal., B 1993, 2, 131.

16. Schmal, M.; Baldanza, M. A. S.; Vannice, M. A.; J. Catal. 1999, 185, 138.

17. Damiani, D. E.; Juan, A.; Konopny, L. W.; Appl. Catal., B 1998, 15, 115 .
18. Maire, G.; Hilaire, L.; Bigey, C.; J. Catal. 1999, 184, 406.

19. Leclercq, G.; El Gharbi, A.; Gengembre, L.; Romero, T.; Pietrzyk, S.; Leclercq, L.; J. Catal. 1994, 148, 550.

20. Wolf, E. E.; Fleisch, T. H.; Regalbuto, J. R.; J. Catal. 1987, 107, 114.

21. Wolf, E. E.; Allen, C. W.; Regalbuto, J. R.; J. Catal. 1987, 108, 304.

22. Baibich, I. M.; dos Santos, J. H. Z.; Stedile, F. C.; Baumvol, I. J. R.; Santarosa, V. E.; Phys. Status Solid B 1995, 192, 519.

23. Baibich, I. M.; dos Santos, J. H. Z.; Stedile, F. C.; Baumvol, I. J. R.; Santarosa, V. E.; Polyhedron 1997, 16, 1937.

24. Baibich, I. M.; dos Santos, J. H. Z.; Gigola, C.; Sica, A. M.; da Silveira, V. C.; Can. J. Anal. Sci. Spectrosc. 1998, 43, 26.

25. Baibich, I. M.; dos Santos, J. H. Z.; Gigola, C.; Sica, A. M.; J. Mol. Catal. A: Chem. 1999, 137, 287.

26. Sica, A. M.; Baibich, I. M.; Gigola, C. E.; J. Mol. Catal. A: Chem. 2003, 195, 225

27. de Oliveira, A. M.; Crize, L. E.; da Silveira, R. S.; Pergher, S. B. C.; Baibich, I. M.; Catal. Commun. 2007, 8, 1293.

28. de Oliveira, A. M.; Baibich, I. M.; Machado, N. R. C. F.; Mignoni, M. L.; Pergher, S. B. C.; Catal. Today 2008, 133, 560.

29. Cónsul, J. M. D.; Peralta, C. A.; Benvenutti, E. V.; Ruiz, J. A. C.; Pastore, H. O.; Baibich, I. M.; J. Mol. Catal. A: Chem. 2006, 246, 33.

30. Cónsul, J. M. D.; Peralta, C. A.; Ruiz, J. A. C.; Pastore, H. O.; Baibich, I. M.; Catal. Today 2008, 133, 475.

31. Cónsul, J. M. D.; Costilla, I.; Gigola, C. E.; Baibich, I. M.; Appl. Catal. A: Gen. 2008, 339, 151.

32. Anderson, J.; Structure of Metallic Catalysts, Academic Press: New York, 1975, p. 296.

33. Topsöe, N. -Y.; Topsöe, H.; J. Catal. 1982, 75, 354.

34. Schmal, M.; Noronha, F. B.; Baldanza, M. A. S.; J. Catal. 1999, 188, 270.

35. Xin, Q.; Yan, Y.; Jiang, S.; Guo, X.; J. Catal. 1991, 131, 234.

36. Zecchina, A.; Garrone, E.; Ghiotti, G.; Coluccia, S.; J. Phys. Chem. 1975, 79, 972.

Received: September 30, 2008 Web Release Date: March 27, 2009 